The work in this paper was sponsored by the United States Atomic Energy Commission and was performed during the tenure by one of us (R.J.F.) of a NATO Fellowship awarded by the Department of Scientific and Industrial Research.

\section{REFERENCES}

Anderson, D. M. W. \& Greenwood, C. T. (1955). J. chem. Soc. p. 225.

Anderson, L., Tomita, K., Kussi, P. \& Kirkwood, S. (1953). J. biol. Chem. 204, 769.

Aspinall, G. O. \& Ferrier, R. J. (1957). Chem. \& Ind. p. 1216.

Auterhoff, H. \& Zeisner, G. (1953). Arch. Pharm., Berl., 286, 525.

Benson, A. A., Bassham, J. A., Calvin, M., Goodale, T. C., Haas, V. A. \& Stepka, W. (1950). J. Amer. chem. Soc. 72, 1710.

Bertrand, G. (1898a). C.R. Acad. Sci., Paris, 126, 842.

Bertrand, G. (1898b). C.R. Acad. Sci., Paris, 126, 984.

Borenfreund, E. \& Dische, Z. (1957). Arch. Biochem. Biophys. 67, 239.

Brimacombe, E., Brimacombe, J. S., Lindberg, B. \& Theander, 0. (1961). Acta chem. scand. 15, 437.

Brock, T. D. (1961). Bact. Rev. 25, 32.

Burton, J. S., Overend, W. G. \& Williams, N. R. (1961). Chem. \& Ind. p. 175.

Butlin, K. R. (1936). Spec. Rep. Chem. Res., Lond., no. 2.
Fulmer, E. I. \& Underkofler, L. A. (1947). Iowa St. Coll. J. Sci. 21, 251.

Hann, R. M., Tilden, E. B. \& Hudson, C. S. (1938). J. Amer. chem. Soc. 60, 1201.

Jones, J. K. N., Perry, M. B. \& Turner, J. C. (1961). Canad. J. Chem. 39, 965.

Kluyver, A. J. \& de Leeuw, F. J. G. (1924). Tijdschr. vergelijk. Geneesk. 10, 170.

Levene, P. A. \& Tipson, R. S. (1936). J.biol.Chem. 115, 731.

Magasanik, B., Franzl, R. E. \& Chargaff, E. (1952). J. Amer. chem. Soc. 74, 2618.

Posternak, T. \& Ravenna, F. (1947). Helv. chim. Acta, 30, 441.

Pratt, J. W., Richtmeyer, N. K. \& Hudson, C. S. (1952). J. Amer. chem. Soc. 74, 2210.

Prince, R. \& Reichstein, T. (1937). Helv. chim. Acta, 20, 101.

Reichstein, T. (1934). Helv. chim. Acta, 17, 996.

Stewart, L. C., Richtmeyer, N. K. \& Hudson, C. S. (1952). J. Amer. chem. Soc. 74, 2206.

Theander, O. (1958). Acta chem. scand. 12, 1887.

Umbreit, W. W., Burris, R. H. \& Stauffer, J. F. (1949). Manometric Techniques and Related Methods for the Study of Tissue Metabolism., 2nd ed. Minneapolis: Burgess Publishing Co.

Visser't Hofft, F. (1925). Biochemische onderzoekingen over het geslacht Acetobacter. Dissertation: Delft.

Whistler, R. L. \& Underkofler, L. A. (1938). J. Amer. chem. Soc. 60, 2507.

Biochem. J. (1962) 83, 14

\title{
The Isolation of $N$-Phosphoryl-lombricine from Earthworms
}

\author{
By A. H. ENNOR AND H. ROSENBERG \\ Department of Biochemistry, John Curtin School of Medical Research, Australian National University, \\ Canberra, A.C.T., Australia
}

(Received 18 August 1961)

A solution containing $N$-phosphoryl-lombricine [D-2-amino-2-carboxyethyl 2-( $N^{\prime}$-phosphorylguanidino)ethyl hydrogen phosphate] (I) was obtained

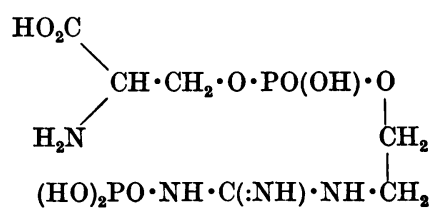

(I)

from earthworms by Thoai, Roche, Robin \& Thiem (1953), but apart from the assessment of a labile P:guanidine-base molecular ratio (of 0.98) its purity was not established and the compound was not isolated as a solid. The isolation of pure $N$ phosphoryl-lombricine was therefore considered desirable, particularly as this compound was re- quired for studies of the enzyme lombricine phosphoryltransferase (Rosenberg, Rossiter, Gaffney \& Ennor, 1960). A preliminary report dealing with the chemical synthesis of $N$-phosphoryl-lombricine has appeared (Beatty, Ennor \& Magrath, 1960), but a rigorous comparison of the synthetic material with the purified natural product has still to be made. This product has now been isolated as a magnesium salt from perchloric acid extracts of earthworms. The present paper describes the isolation procedure, which gives an analytically pure product in yields in excess of $70 \%$ of that present in the original extracts.

\section{MATERIALS AND METHODS}

The earthworms used were as described by Rosenberg \& Ennor (1959), care being taken to choose batches that were 'live-frozen' and which had been stored at $-70 \%$ since 
collection some months previously. These were of a mixed species, but predominantly Octolasium cyaneum and Allolobophora caliginosa. All reagents used were analyticalgrade, as were the ion-exchange resins (Fluka A.-G., ex Dow Chemical Co. and supplied by Chemische Fabrik Buchs, Switzerland). The resins were initially 'batchwashed' by repeated suspension in large volumes of water and decantation of the supernatant. They were then converted into the appropriate form in the following manner.

Dowex $50\left(\mathrm{NH}_{4}^{+}\right.$form). Dowex 50 (X4; mesh 200-400), supplied in the $\mathrm{H}^{+}$form, was transferred to a column $(8 \mathrm{~cm} . \times 60 \mathrm{~cm}$.) and $\mathrm{NaOH}(2.5 \mathrm{~N}$ containing $0.2 \%$ of EDTA) passed through until the 'front', detectable as a dark, hot band, had disappeared at the bottom of the column. An additional $2 \mathrm{l}$. of alkaline solution was then passed through the column. The column was washed with

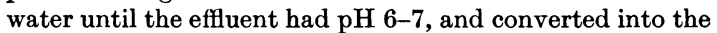
$\mathrm{H}^{+}$form by passing excess of $2 \cdot 5 \mathrm{~N} \cdot \mathrm{HCl}$ through the column; the latter was then washed with water until the washings were free of $\mathrm{Cl}^{-}$ions. The column was next treated with excess of aq. $2 \cdot 5 \mathrm{~N}-\mathrm{NH}_{3}$ and washed with water until the effluent was free from $\mathrm{NH}_{4}{ }^{+}$ions, as judged by a negative reaction with Nessler's reagent. The resin was stored in the wet condition until required.

Dowex $1\left(\mathrm{HCO}_{3}^{-}\right.$form). Dowex 1 (X 10; mesh 200-400) and Dowex 1 (X1;50-100), supplied in the $\mathrm{Cl}^{-}$form, were transferred to a column $(60 \mathrm{~cm} . \times 8 \mathrm{~cm}$. $)$ and a solution of $\mathrm{NaHCO}_{3}$ [about $18 \%(\mathrm{w} / \mathrm{v})$ ] passed through until the effluent was $\mathrm{Cl}^{-}$-free. The column was then washed exhaustively with water and the resin stored in the wet condition until required.

Chemical determinations. Lombricine was determined by the method described for arginine (Rosenberg, Ennor \& Morrison, 1956) and $N$-phosphoryl-lombricine was determined as the difference between the 'free' lombricine and that released after hydrolysis for $2 \mathrm{~min}$. at $100^{\circ}$ in $2 \mathrm{~N}-\mathrm{HCl}$. Inorganic phosphate was determined according to King (1932) after wet-ashing a sample (about $5 \mathrm{mg}$.) of the material with $\mathrm{H}_{2} \mathrm{SO}_{4}$ and $\mathrm{HNO}_{3}$ and conversion of the resultant pyrophosphate into orthophosphate by heating for $1 \mathrm{hr}$. at $100^{\circ}$ in $\mathrm{N}-\mathrm{H}_{2} \mathrm{SO}_{4}$. Magnesium was determined after combustion of the solid sample (about $5 \mathrm{mg}$.) and heating the residue, to which a small excess of phosphoric acid had been added, to constant weight. The residue of magnesium pyrophosphate was fused with $\mathrm{Na}_{2} \mathrm{CO}_{3}$, dissolved in boiling $2 \mathrm{~N}-\mathrm{HCl}$ and heated on the boiling-water bath for $1 \mathrm{hr}$. to convert the pyrophosphate into orthophosphate. The resultant solution was made to known volume and samples were taken for phosphate determination.

\section{Isolation of $\mathrm{N}$-phosphoryl-lombricine}

Frozen earthworms (6 kg.) were extracted in $200 \mathrm{~g}$. batches in a Waring Blendor for $1 \mathrm{~min}$. in $300 \mathrm{ml}$. of $1 \cdot 5 \mathrm{~N}-\mathrm{HClO}_{4}$. Each suspension immediately after preparation was strained through several layers of gauze into a vessel containing $15 \mathrm{~g}$. of Hyflo Supercel, mixed and filtered by suction. The opalescent filtrate was adjusted to $\mathrm{pH} 7-$ 7.5 by the addition of $10 \mathrm{~N}-\mathrm{KOH}$ to the vigorously stirred solution, the $\mathrm{pH}$ of which was checked throughout by a glass electrode. The time elapsing between commencement of extraction and neutralization was about $4 \mathrm{~min}$., and a temperature of $-3^{\circ}$ to $0^{\circ}$ was maintained up to neutralization. This step required 4-7 sec., during which the tem- perature rose to about $15^{\circ}$. The neutralized extract was rapidly cooled to $0^{\circ}$ and the combined extracts were kept overnight at $0^{\circ}$ to ensure maximum precipitation of $\mathrm{KClO}_{4}$. The suspension was then centrifuged, the residue (mainly $\mathrm{KClO}_{4}$ ) discarded and the supernatant further clarified by passage through a Sharples centrifuge. The total volume of the extract was $9 \mathrm{l}$. and on analysis contained $1.6 \mathrm{~g}$. of $N$-phosphoryl-lombricine. The extract was passed, at $60 \mathrm{ml} . / \mathrm{min}$., through a column $(50 \mathrm{~cm} . \times 8 \mathrm{~cm}$.) of Dowex 1 resin (XI; mesh $50-100 ; \mathrm{HCO}_{3}^{-}$form), as described by Martonosi (1960). The column was then washed with water until the effluent was lombricine-free. The washings and effluent were combined and retained for subsequent isolation of lombricine and serine ethanolamine phosphodiester (Ennor, Rosenberg, Rossiter, Beatty \& Gaffney, 1960). The column was then eluted with an increasing gradient of $\mathrm{KHCO}_{3}$, essentially as described by Hurlbert, Schmitz, Brumm \& Potter (1954). The volume of water above the column was $950 \mathrm{ml}$. and the mixing vessel contained 11. of water; this vessel was connected to a supply vessel which initially contained 11 . of $0.5 \mathrm{M}-\mathrm{KHCO}_{3}$. When this solution had been transferred to the mixing vessel it was successively replaced by 11 . of $1 \mathrm{M}$ - and 21 . of $1.5 \mathrm{M}-\mathrm{KHCO}_{3}$. The eluate was collected in $30 \mathrm{ml}$. fractions at $12 \mathrm{ml} . / \mathrm{min}$. $N$-Phosphoryl-lombricine appeared in the eluate after $2.9 \mathrm{l}$. had emerged and was completely eluted from the column by a further $850 \mathrm{ml}$. The fractions containing this volume of eluate were combined, cooled to $0^{\circ}$ and brought to $\mathrm{pH} \mathrm{3-3.5}$ by the slow addition of $12 \mathrm{~N}$ $\mathrm{HClO}_{4}$, while the mixture was vigorously aerated and exposed to reduced pressure to remove $\mathrm{CO}_{2}$; the mixture was then adjusted to $\mathrm{pH} 7$ with $\mathrm{N}-\mathrm{KOH}$. The precipitated $\mathrm{KClO}_{4}$ was removed by filtration and discarded. To the filtrate (1025 ml.), which contained $1.3 \mathrm{~g}$. of $N$-phosphoryllombricine, was added $50 \mathrm{ml}$. of a $20 \%(\mathrm{w} / \mathrm{v})$ solution of magnesium acetate in $50 \%(v / v)$ ethanol (referred to below as 'magnesium acetate solution'), followed by 3 vol. of ethanol, and the mixture readjusted to $\mathrm{pH} 7$ by the addition of $\mathrm{N}-\mathrm{KOH}$. The flocculent precipitate was collected by centrifuging and the supernatant fluid discarded. The precipitate was washed by twice suspending it in ethanol and once in acetone, and finally dried under reduced pressure over $\mathrm{P}_{2} \mathrm{O}_{5}$. The dry material (4.2 g.) was suspended in water (about $40 \mathrm{ml}$.) and the suspension adjusted to $\mathrm{pH} 7$ by the addition of $1.5 \mathrm{~N}-\mathrm{HClO}_{4}$ and centrifuged. The residue was thrice suspended in water $(20 \mathrm{ml}$.) and the supernatants were combined with the first extract and readjusted to $\mathrm{pH} 7$. Magnesium acetate solution $(1 \mathrm{ml}$.) was added, followed by ethanol (4 vol.), and the magnesium salt recovered by centrifuging and dried as described above. It was dissolved in $20 \mathrm{ml}$. of water and the solution passed through a column $(55 \mathrm{~cm} . \times 5 \mathrm{~cm}$.) of Dowex 50 resin (mesh 200-400; $\mathrm{NH}_{4}{ }^{+}$-form), followed by water, at $15 \mathrm{ml}$./ $\mathrm{min}$. The effluent was collected in $25 \mathrm{ml}$. fractions and those containing $N$-phosphoryl-lombricine were combined to give a total volume of $200 \mathrm{ml}$. Magnesium acetate solution $(20 \mathrm{ml}$.) was added, the mixture brought to $\mathrm{pH} 9$ by the addition of aq. $2 \mathrm{~N}-\mathrm{NH}_{3}$ and kept overnight at $0^{\circ}$ to permit precipitation of a small amount of inorganic $\mathbf{P}$ as sodium ammonium hydrogen phosphate. This was removed by filtration and the magnesium salt of $N$-phosphoryllombricine precipitated by the addition of 3 vol. of ethanol. The suspension was centrifuged, the supernatant discarded and the residue washed with ethanol, acetone and dried as 
before. The dry material was dissolved in water $(50 \mathrm{ml}$.) and the solution passed through a column $(15 \mathrm{~cm} . \times 3 \mathrm{~cm}$.) of Dowex 50 resin (mesh $200-400 ; \mathrm{NH}_{4}{ }^{+}$form), and thus converted into the ammonium salt. The column was washed with water until the washings were free from $N$-phosphoryl-lombricine and the washings were combined with the original effluent. This solution was applied to a column (55 cm. $\times 5 \mathrm{~cm}$.) of Dowex 1 resin (mesh 200-400; $\mathrm{HCO}_{3}{ }^{-}$form). The adsorbed material was eluted as before with an increasing concentration gradient of $\mathrm{KHCO}_{3}$ and the eluate collected automatically in $25 \mathrm{ml}$. fractions. $N$-Phosphoryl-lombricine appeared in the eluate after $2.4 \mathrm{l}$. had been collected and was completely eluted from the column by a further $575 \mathrm{ml}$. Those fractions containing $N$-phosphoryl-lombricine were pooled, the $\mathrm{HCO}_{3}^{-}$ions decomposed and the $\mathrm{CO}_{2}$ removed as before. The volume of the $\mathrm{CO}_{2}$-free solution was $700 \mathrm{ml}$. (pH 7) and on analysis it contained $1.23 \mathrm{~g}$. of $N$-phosphoryl-lombricine. Magnesium acetate solution $(10 \mathrm{ml}$.) was added together with 2.51 . of ethanol and the mixture kept for $\mathbf{3 0} \mathrm{min}$. after adjustment to $\mathrm{pH} 7$ by the addition of $\mathrm{N}-\mathrm{KOH}$. The mixture was centrifuged, the supernatant discarded and the residue washed with ethanol and acetone and dried as before. The dry material was dissolved in about $30 \mathrm{ml}$. of water. A small amount of insoluble residue was removed by centrifuging and resuspended in $10 \mathrm{ml}$. of water. The suspension was centrifuged, the wash combined with the original supernatant and the residue discarded. The clear solution was passed through a column $(15 \mathrm{~cm} . \times 3 \mathrm{~cm}$.) of Dowex 50 resin (mesh 200-400; $\mathrm{NH}_{4}^{+}$form), followed by $\mathrm{CO}_{2}$-free water. The effluent fractions containing $N$-phosphoryllombricine were pooled and diluted to about $100 \mathrm{ml}$. $\left(\mathrm{CO}_{2^{-}}\right.$ free water was used entirely from this stage on.) Magnesium acetate solution $(10 \mathrm{ml}$.) was added, followed by $350 \mathrm{ml}$. of ethanol which had been stored over $\mathrm{Mg}(\mathrm{OH})_{2}$, and the precipitate collected, washed once with $75 \%(v / v)$ ethanol, once with $95 \%(v / v)$ ethanol, once with acetone and twice with ether. The residue was dried in vacuo, dissolved in about $50 \mathrm{ml}$. of water, and the precipitation with magnesium acetate and washing were repeated. The residue was finally dried in vacuo at room temperature over $\mathrm{KOH}$ for 5 days. A sample for analysis was kept continuous over $\mathrm{KOH}$, and extreme precautions were taken, since the material appeared to show increased carbon content on exposure to air, presumably by adsorption of $\mathrm{CO}_{2}$.

Samples of the final product, when hydrolysed in $\mathrm{N}-\mathrm{HCl}$ at $100^{\circ}$ for $5 \mathrm{~min}$., showed no trace of ninhydrin-reacting material other than lombricine, as judged by chromatography in a two-dimensional system (water-saturated phenol and ethanol-formic acid-water (7:1:2, by vol.).

The preparation yielded $1.52 \mathrm{~g}$. of the magnesium salt, and calculation of molecular ratios showed that 1.5 atoms of $\mathrm{Mg}$ and $4 \mathrm{~mol}$. of water were present $/ \mathrm{mol}$. of $N$-phos. phoryl-lombricine. The yield was thus $1 \cdot 16$ g., which represents a $73 \%$ recovery of that present in the initial extract. (Found: C, 16.3; H, 4.8; N, 12.1; P, 13.5; Mg, 8.0. $\mathrm{C}_{6} \mathrm{H}_{13} \mathrm{Mg}_{1 \cdot 5} \mathrm{~N}_{4} \mathrm{O}_{9}, 4 \mathrm{H}_{2} \mathrm{O}$ requires $\mathrm{C}, 15 \cdot 8 ; \mathrm{H}, 4 \cdot 6 ; \mathrm{N}, 13.2$; P, 13.6; Mg, 8.0\%).

\section{DISCUSSION}

The present method for the isolation of $N$. phosphoryl-lombricine differs in several respects from those that have been used for preparing other phosphagens from natural sources. Analytically pure preparations of $N$-phosphorylarginine and $N$ phosphorylcreatine have been obtained by the use of conventional precipitation techniques and the compounds have been isolated as salts of the alkaline-earth materials (cf. Ennor \& Morrison, 1958). These methods depend on the high solubility of such salts in aqueous media and on their relative insolubility in $80 \%$ aqueous ethanol. With $N$-phosphoryl-lombricine such methods are of little value because the barium and calcium salts are precipitated from aqueous solution at low concentrations of ethanol and are heavily contaminated by free lombricine, as well as by clay and other insoluble matter found in worms and not in other biological material. Consequently ion-exchange resins have been used for isolating, in good yield, $N$-phosphoryl-lombricine as the magnesium salt. The material appears to be quite stable and has shown no sign of decomposition when stored at room temperature in a sealed bottle for over a year.

Several attempts have been made to prepare other salts but for various reasons these were unsatisfactory. Thus the sodium and potassium salts were deliquescent and the cyclohexylamine salt was unstable. The ammonium salt has been prepared and is stable, but, as its preparation involves an additional step, it possessed no advantage. The magnesium salt is extremely soluble in water and is similar in acid-instability to $N$-phosphorylarginine or the other naturally occurring $N$-phosphorylated monosubstituted guanidines. The structure of $N$ phosphoryl-lombricine suggests that its stability in acid solution would probably be enhanced by the addition of molybdate (cf. Ennor \& Morrison, 1958).

The isolation of $N$-phosphoryl-lombricine in good yields from crude extracts emphasizes the advantages of the Dowex 1 ( $\mathrm{HCO}_{3}^{-}$form) column (Martonosi, 1960) for fractionating similar labile compounds. The advantages of ion-exchange resins in the $\mathrm{HCO}_{3}{ }^{-}$form have been recently discussed by Cohn \& Bollum (1961).

The absolute yield of $N$-phosphoryl-lombricine from frozen earthworms depends entirely on the state of the animals at the time of collection and presumably on the speed of the subsequent freezing, and varies with the batch of material used. Our final yield of analytically pure material varied from 0.17 to $0.29 \mathrm{~g}$. of $\mathrm{N}$-phosphoryl-lombricine ( $\mathrm{Mg}$ salt) $/ \mathrm{kg}$. of earthworms.

\section{SUMMARY}

1. A procedure for isolating analytically pure $N$-phosphoryl-lombricine (magnesium salt) from perchloric acid extracts of frozen earthworms is 
described. The procedure employs anion- and cation-exchange resins for the major purification steps and produces yields of $N$-phosphoryllombricine in excess of $\mathbf{7 0} \%$ of that present in the original extracts.

Our thanks are due to Dr Joyce Fildes for elementary analyses and to $\mathrm{Mr} \mathrm{B}$. Thorpe for skilled technical assistance.

\section{REFERENCES}

Beatty, I. M., Ennor, A. H. \& Magrath, D. I. (1960). Nature, Lond., 188, 1026.

Cohn, W. E. \& Bollum, F. J. (1961). Biochim. biophys. Acta, 48, 588 .
Ennor, A. H. \& Morrison, J. F. (1958). Physiol. Rev. 38, 631.

Ennor, A. H., Rosenberg, H., Rossiter, R. J., Beatty, I. M. \& Gaffney, T. J. (1960). Biochem. J. 75, 179.

Hurlbert, R. B., Schmitz, H., Brumm, A. F. \& Potter, V. R. (1954). J. biol. Chem. 209, 23.

King, E. J. (1932). Biochem. J. 26, 292.

Martonosi, A. (1960). Biochem. biophys. Res. Commun. 2, 12.

Rosenberg, H. \& Ennor, A. H. (1959). Biochem. J. 73, 521.

Rosenberg, H., Ennor, A. H. \& Morrison, J. F. (1956). Biochem. J. 63, 153.

Rosenberg, H., Rossiter, R. J., Gaffney, T. \& Ennor, A. H. (1960). Biochim. biophys. Acta, 37, 385.

Thoai, N. v., Roche, J., Robin, Y. \& Thiem, N. v. (1953). C.R. Soc. biol., Paris, 147, 1670.

Biochem. J. (1962) 83, 17

\title{
The Purification and Properties of Phospholipase A from Human Pancreas
}

\author{
By W. L. MAGEE,* JENNIFER GALLAI-HATCHARD, HAZEL SANDERS \\ AND R. H. S. THOMPSON \\ Department of Chemical Pathology, Guy's Hospital Medical School, Lonḋon, S.E. 1
}

(Received 27 July 1961)

Although phospholipase A (phosphatide acylhydrolase, EC 3.1.1.4) has been shown to occur in a number of animal tissues (Zeller, 1951) the pancreas appears to be the richest mammalian source of the enzyme. Its presence was first suggested by the work of Bokay (1877), but more definite proof of its existence in pancreas was not provided until considerably later (Belfanti \& Arnaudi, 1932; Gronchi, 1936). Since then pancreatic phospholipase $A$ has been the subject of considerable research, a variety of techniques being used for the assay and isolation of the enzyme, sometimes with conflicting results (Ercoli, 1940).

Gronchi (1936) isolated phospholipase A by extracting commercial pancreatin with aqueous $50 \%$ ethanol at $90^{\circ}$. Hanahan (1952) employed the same starting material to obtain a partially purified preparation that was active in diethyl ether; extracts of fresh rat pancreas also converted lecithin into lysolecithin in the ethereal reaction system. The preparation and purification of phospholipase A from aged ox pancreas was described by Rimon \& Shapiro (1959), who used a phosphatebuffered assay system. Very recently, a method has been described for the measurement of phospholipase $\mathbf{A}$ in duodenal contents, serum and other

* Postdoctoral Fellow of the National Multiple Sclerosis Society. body fluids (Vogel \& Zieve, 1960; Zieve \& Vogel, 1961).

This paper represents a continuation (Magee \& Thompson, 1960) of a project designed to devise a reaction system suitable for the accurate assessment of phospholipase $A$ in animal tissues, and to compare the properties of phospholipase A preparations isolated from various sources. Human pancreas was used as the enzyme source because it contains an active phospholipase $A$ and because human pancreatic tissue had not been investigated previously. A relatively simple method for the purification of the enzyme is described and some of its properties are discussed.

\section{MATERIALS}

Ovolecithin. Ovolecithin was prepared, stored and washed free of $\mathrm{Ca}^{2}+$ ions as described by Magee \& Thompson (1960). For certain experiments, the ovolecithin $(1 \mathrm{mg} . / \mathrm{ml}$.) was emulsified in mM-EDTA and then mixed with 4 vol. of chloroform-methanol $(2: 1, \mathrm{v} / \mathrm{v})$. Phase separation was assisted by centrifuging. The lower phase was washed with upper-phase solvents (Folch, Lees \& Sloane-Stanley, 1957), taken to dryness and the lipid made up as a stock solution in chloroform.

Lysolecithin. Pure lysolecithin was prepared in this Laboratory by Dr G. R. Webster as described by Marples, Thompson \& Webster (1958). 